\title{
Vitamin D3 Adjuvant Treatment Stimulate Interleukin-10 Expression in Children with Nephrotic Syndrome Without Affecting to Clinical Outcome and Glucocorticoid Receptor Expression
}

\author{
Husnul Asariati ${ }^{1^{*}}$, Krisni Subandiyah ${ }^{1}$, Loeki Enggar Fitri ${ }^{2}$ \\ ${ }^{1}$ Department of Child Health, Faculty of Medicine, University of Brawijaya/ \\ dr. Saiful Anwar General Hospital, Malang, 65122 Indonesia \\ ${ }^{2}$ Department of Parasitology, Faculty of Medicine, University of Brawijaya ,Malang, 65145 Indonesia
}

\begin{abstract}
Idiopathic nephrotic syndrome (INS) is the most glomerular disease that occurred in childhood with high rate morbidity. Glucocorticoid is drug of choice for INS and responsiveness to this drug determined prognosis. Glucocorticoid upregulate transcription of anti-inflammatory cytokines such as IL-4 and IL-10. IL-10 is an antiinflammatory cytokine and has multiple role in immune response include modulate Th1/Th2 response. Vitamin D3 interact with glucocorticoid signaling. Administered active form of vitamin D3 increase dexamethasoneinduced IL-10 expression by regulatory T cells in steroid resistant asthmatic patient. Here we showed increase of $\mathrm{CD} 4^{+} \mathrm{IL} 10^{+}$expression after treatment both prednisone only and combination prednison with vitamin D3. Both in new-onset NS or rare relaps NS, combination treatment prednisone + vitamin D3 increase CD4 ${ }^{+} \mathrm{IL} 10^{+}$expression significantly compared to prednisone-only treated group ( $\mathrm{p}=0.003$ ), which first group (new-onset nephrotic syndrome + prednisone and vitamin D3 treatment) showed the most CD4 ${ }^{+} \mathrm{IL} 10^{+}$expression enhancement (9.53 \pm 3.89$)$. However this study failed to show a correlation between $\mathrm{CD} 4^{+} \mathrm{IL}-10^{+}$expression after prednisone and vitamin D3 treatment with clinical outcome (linear regression test, $p=0,125$ ). This study also showed that there was a no correlation between $\mathrm{CD} 4^{+} \mathrm{IL}-10^{+}$expression and $\mathrm{CD}_{3}^{+} \mathrm{GR}$ expression after prednison + vitamin $\mathrm{D} 3$ treatment $(p=0.088)$. CD4 $4^{+} \mathrm{IL}-10^{+}$expression in new-onset and rarely relapsing nephrotic syndrome patients higher in prednisone + vitamin D3 treated group than prednisone-only treated group. There is no correlation between $\mathrm{CD} 4^{+} \mathrm{IL}-10^{+}$expression and $\mathrm{CD}_{3}{ }^{+} \mathrm{GR}$ expression nor $\mathrm{CD} 4^{+} \mathrm{IL}-10^{+}$expression and clinical outcome.
\end{abstract}

Keywords: $C D 3^{+} G R, C D 4^{+} I L-10^{+}$, idiophatic nephrotic syndrome, prednisone, vitamin D3

\section{INTRODUCTION}

Idiopathic nephrotic syndrome (INS) is the most glomerular disease occurred in childhood, account for $85 \%$ from all children with nephrotic syndrome $[1,2]$. Annual incidence of nephrotic syndrome in healthy children is estimated 2 to 7 cases per 100,000 children younger than 18 years of age. The peak age of onset occurs at 2 to 3 years, and approximately $50 \%$ of affected children are ages 1 to 4 years; $75 \%$ are younger than age 10 years [3]. Hospitalization rate of INS in dr Saiful Anwar Hospital, Malang, Indonesia from January 2002 until Desember 2006 was 101 cases (34\% from 297 cases in nephrologic inpatient wards) [4].

Mechanism that underlying pathogenesis of

${ }^{*}$ Corresponding author:

Husnul Asariati

Department of Child Health, Faculty of Medicine, University of Brawijaya/dr. Saiful Anwar General Hospital, Malang, Indonesia husnulasariati@gmail.com nephrotic syndrome is still unclear. Nephrotic syndrome is mediated by immunologic abnormalities. There is an evidence that nephrotic syndrome caused by circulating factor, T-cell associated, which can cause podocyte disfunction lead to massive proteinuria [5]. Some evidence showed association between INS (primary immunologic impairment) and imbalance of Th1 and Th2 subtype as immunoregulator $[1,6,7]$. In vitro study using peripheral blood mononuclear cell (PBMC) isolated from INS patients showed increase level of various cytokines such as Interleukin (IL)-1 IL2 , IL-4 and tumor necrosis factor (TNF)- $\alpha$, compared to control group or INS patients at remission state group. Other study using PBMC from patients with INS showed decrease of IL-10 serum level and increase of IL-12 and IL-18 serum level compared to control group [8].

Glucocorticoid is drug of choice for INS and responsiveness to this drug determined prognosis [9]. 
Approximately $85 \%-90 \%$ patients with INS have a good response to glucocorticoid therapy and remit completely from proteinuria, otherwise $10 \%-15 \%$ have a partial or no response to glucocorticoid treatment [9, 10]. The mechanism underlying unresponsiveness to glucocorticoid treatment is complex. It based on physiologic process that involved in glucocorticoid signaling. Glucocorticoid bind to cytoplasmic glucocorticoid receptor (GR), and then translocate to nucleus and regulate transcription process of several protein include cytokines [10-13]. Glucocorticoid downregulate transcription of pro-inflammatory cytokines such as IL1, IL-2, IL-6, IL-8, IL-11, IL-12, TNF- $\alpha$, Interferon gamma (IFN)- $\gamma$, granulocyte-macrophage colony stimulating factor (GM-CSF) and upregulate transcription of anti-inflammatory cytokines as IL-4 and IL-10 [14].

Interleukin-10 is an anti-inflammatory cytokine and has multiple role in immune response include modulate Th1/Th2 response via APC (Antigen Presenting Cells) and directly inhibit proliferation and cytokine synthesis by $\mathrm{T}$ cells [15-17]. In steroid resistant asthmatic patient, IL-10 increase GR expression via $\mathrm{T}$ CD4+ cells. Ligand-induced GR downregulation can be reserved by vitamin D3. Vitamin D3 interact with glucocorticoid signaling. Administered active form of vitamin D3 increase dexamethasone-induced IL-10 expression by regulatory $\mathrm{T}$ cells in steroid resistant asthmatic patient. Pre-incubation T cell with IL-10 and vitamin D3 can improve impairment IL-10 release from $\mathrm{T}$ cell that induced by dexamethasone [18].

Active form of vitamin D3, 1,25( $\mathrm{OH}) 2$-dihydroxyvitamin D3, not only has a role in calcium metabolism but also modulate immune response [19]. Terrier, et al. showed that vitamin $\mathrm{D}$ was safe and induced decrease of memory B cells, increase Treg and decrease Th1 and Th17 effector cells [20]. In vitro study of T $\mathrm{CD} 4^{+}$cell culture conducted by Urry, et al. showed that active form of vitamin D3 increased population of $\mathrm{CD} 4^{+} \mathrm{IL}-10^{+}$and $\mathrm{CD} 4^{+}$Foxp $3^{+}$cells [21].

This current study aimed to compare the effect of combination therapy of corticosteroid (prednisone) and vitamin D3 with corticosteroid-only therapy on $\mathrm{CD} 4^{+} \mathrm{IL}-10^{+}$expression. This study also investigate the correlation between $\mathrm{CD} 4^{+} \mathrm{IL}-10^{+}$and $\mathrm{CD}^{+} \mathrm{GR}$ expression, $\mathrm{CD} 4^{+} \mathrm{IL}-10^{+}$expression and clinical outcome (steroid resistant or steroid sensitive nephrotic syndrome). We hypothesized that combination therapy increase $\mathrm{CD}^{+} \mathrm{IL}-10^{+}$expression more than prednisoneonly treated group both in new-onset nephrotic syndrome and rare relaps nephrotic syndrome. We also hypothesized that there is a correlation between $\mathrm{CD} 4^{+} \mathrm{IL}-10^{+}$expression and $\mathrm{CD} 3^{+} \mathrm{GR}$ expression as well as clinical outcome.

\section{MATERIALS AND METHODS \\ Study Design}

This experimental study was conducted in pediatric nephrology policlinic and pediatric nephrology inpatient ward at dr. Saiful Anwar Hospital, Malang, Indonesia between October 2013 and April 2014. During this period 24 children in the age group 4-12 years with new onset idiopathic nephrotic syndrome (INS) were prospectively studied. Design of this study was an experimental study with randomized clinical trial, double blind, pre and post test control group. Blood samples (GR assays and IL-10 assay) obtained two times (before and after treatment). 24 patients divided into 4 groups consist of new onset INS that treated with prednisone only as a first group, new onset of INS treated with combination of prednisone and vitamin D3 as a second group, rare relaps INS treated with prednisone only as the third group, and rare relaps INS treated with combination of prednisone and vitamin D3 as the forth group. Prednisone was given orally at dose $2 \mathrm{mg} / \mathrm{kg} /$ day for 4 weeks. Vitamin D3 (D-Vit, GraciaPharmindo) also given orally at dose 2000 IU for 4 weeks. This study had been approved by Ethical Committee of dr. Saiful Anwar Hospital Malang, Indonesia.

\section{Patients}

Blood samples were obtained from 24 patients (19 males, 31 females, aged 4-12 years) with nephrotic syndrome and had received treatment both in nephrology polyclinic and inpatient ward during experimental study. Inclusion criteria include: diagnosed as idiopathic nephrotic syndrome (classified as first diagnosed and intermittent relapse), age range between 1-14 years old, approved by parents to participate in this study. Exclusion criteria for this study: secondary and congenital nephrotic syndrome, frequent relapse nephrotic syndrome, and steroid resistance nephrotic syndrome. Subjects that met the inclusion criteria randomized using randomization table.

\section{PBMC Isolation}

Blood sample transferred from collection vacuum tubes (previously mixed with anticoagulant EDTA) to a $50 \mathrm{~mL}$ tube. An equal volume of PBS was added and sample was mixed by repeated pipetting. The second $50 \mathrm{~mL}$ tube was prepared and filled with Ficoll- 
Hipaque $(\mathrm{d}=1.077 \mathrm{~g} / \mathrm{mL})$. This Ficoll-Hipaque solution carefully layer with the diluted blood with equal volume and then centrifuged at $1000 \mathrm{rpm}$ for 30 minutes. PBMC layer was removed (second layer) using micropipette and transfered to a new $15 \mathrm{~mL}$ centrifuge tube. After washing two times using PBS $10 \mathrm{~mL}$ and centrifuge at $1200 \mathrm{rpm}$ for 10 minutes, decant the supernatant and re-suspend the cell pellet in appropriate volume of PBS.

\section{Assay for $C D 3^{+}$GR Expression}

Phycoerythrin (PE)-labelled antihuman CD357 (GITR) (antibody cat\# 311604, Biolegend, USA) and FITC-labelled anti-human CD3 (antibody cat\# 344804, Biolegend, USA) were used for intracelullar staining (flowcytometry). $\mathrm{T}$ cell lymphocyte added with cell staining buffer ( $2 \%$ fetal bovine serum in PBS). Five $\mu \mathrm{l}$ pellet from PBMC isolation was taken and ready for staining using FITC-labelled anti-human CD3. $50 \mu \mathrm{l}$ diluted antibody was taken and mixed with $\mathrm{T}$ cell lymphocyte and then incubated for 20 minutes (in dark room temperature). After this incubation, samples were ready for GR staining. Cell were washed with $500 \mu \mathrm{l}$ cell staining buffer, centrifuged at $4^{\circ} \mathrm{C}, 2500 \mathrm{rpm}$ for 3 minutes. After removing the supernatant, $\mathrm{T}$ cell lymphocyte washed with $500 \mu \mathrm{l}$ fix buffer solution, homogenized and centrifuged at $4^{\circ} \mathrm{C}, 2500 \mathrm{rpm}$ for 3 minutes. Supernatant were removed, $\mathrm{T}$ cell lymphocyte fixed with $500 \mu \mathrm{l}$ fix buffer and then incubated for 20 minutes (in dark room temperature). After incubation, samples were centrifuged at $4^{\circ} \mathrm{C} 2500 \mathrm{rpm}$ for $3 \mathrm{~min}$ utes. Supernatant were removed, and then cells washed again, re-suspend in permeabilization buffer. Suspensions were centrifuged again at $4^{\circ} \mathrm{C}, 2500 \mathrm{rpm}$ for 3 minutes. After removing the supernatant, cells were ready for cell surface staining with PE-labelled anti-human CD357 (GITR) antibody (1:250). Each solution stained with $50 \mu \mathrm{l}$ PE anti-human CD357 (GITR) diluted antibody, incubated at dark room for 20 minutes, and then washed with $500 \mu \mathrm{l}$ permeabilization wash buffer solution. After centrifugation at $4^{\circ} \mathrm{C}, 2500 \mathrm{rpm}$ for 3 minutes, supernatant were removed and added with $350 \mu \mathrm{l}$ cell staining buffer. Cell samples were run on FACS Calibur flowcytometer and analyzed by BD Cell Quest Pro software.

\section{Assay for CD4 IL-10 Expression}

PerCP/Cy5.5-labelled anti-human IL-10 (cat\# 501418, Biolegend, USA) and FITC-labelled anti-human CD4 antibody (cat\# 300506, Biolegend,USA) intracellular staining (flowcytometry). $\mathrm{T}$ lymphocytes
$\mathrm{CD}^{+}$added with cell staining buffer ( $2 \%$ fetal bovine serum in PBS). Five $\mu$ l pellet from PBMC isolation was taken and ready for staining using FITC-labelled antihuman CD4. $50 \mu \mathrm{l}$ diluted antibody was taken and mixed with $\mathrm{T}$ cell lymphocyte and then incubated for 20 minutes (in dark room temperature). After this incubation, sample was ready for IL-10 intracellular staining. Cells were washed with $500 \mu \mathrm{l}$ cell staining buffer, centrifuged at $4^{\circ} \mathrm{C}, 2500 \mathrm{rpm}$ for 3 minutes. After removing the supernatant, $\mathrm{T}$ lymphocytes $\mathrm{CD}^{+}$ washed with $500 \mu \mathrm{l}$ fix buffer solution, homogenized and centrifuged at $4^{\circ} \mathrm{C}, 2500 \mathrm{rpm}$ for 3 minutes. Supernatant were removed, $\mathrm{T}$ lymphocytes $\mathrm{CD} 4^{+}$fixed with $500 \mu \mathrm{l}$ fix buffer and then incubated for 20 minutes (dark, room temperature). After incubation, samples were centrifuged at $4^{\circ} \mathrm{C}, 2500 \mathrm{rpm}$ for 3 minutes. Supernatant were removed, and then cells washed again, re-suspend in permeabilization buffer. Suspensions were centrifuged again at $4^{\circ} \mathrm{C}, 2500 \mathrm{rpm}$ for 3 minutes. After removing the supernatant, cells were ready for staining with PerCP/Cy5.5-labelled anti-human IL-10 antibody (1:250). Each solution stained with $50 \mu \mathrm{l}$ PerCP/Cy5.5 anti-human IL-10 diluted antibody, incubated at dark room for 20 minutes, and then washed with $500 \mu \mathrm{l}$ permeabilization wash buffer solution After centrifugation at $4^{\circ} \mathrm{C}, 2500 \mathrm{rpm}$ for 3 minutes, supernatant were removed and added with $350 \mu$ cell staining buffer. Cell samples were run on FACS Calibur flow cytometer and analyzed by BD Cell Quest Pro software.

\section{Statistical Analysis}

The normality of distribution was confirmed by the Saphiro-Wilk'sW-test (normal distribution assumed as Sig or $\mathrm{p}>0.05)$. The difference in IL-10 expression in particular lymphocyte subpopulations between prednisone-only and combination of prednisone and vitamin D3 treated group confirmed by one-way ANOVA (Kruskal-Wallis test as an alternative test). The diference in IL-10 expression before and after treatment confirmed by paired t-test (Wilcoxon test as an alternative). Correlation between IL-10 expression with outcome and GR expression among patients that given vitamin D3 as adjuvant (steroid sensitive or steroid resistant nephrotic syndrome) confirmed by regression test. Data were analyzed using SPSS for Windows 17.0. (confidence interval 95\%).

\section{RESULTS AND DISCUSSION}

This study involved 24 patients age ranged from 412 years with nephrotic syndrome (12 patient new-on- 
set nephrotic syndrome and 12 patients rare relaps nephrotic syndrome). Patients divided randomized into 4 treated groups. The first and second group consists of 6 patients with new onset nephrotic syndrome. First group treated with prednisone only, and second group treated with combination of prednisone and vitamin D3. The third and fourth group consists of 6 patient with rarery relapsing nephrotic syndrome. The third group treated with prednisone only, and fourth group treated with combination of prednisone and vitamin D3. Among all groups, there was no drop out. During 4 weeks treatment, patients were not showed any illness or adverse drug reactions caused by prednisone or vitamin D3.

\section{CD4 $I L 10^{+}$expression}

Table 1 showed that $\mathrm{CD}^{+} \mathrm{IL} 10^{+}$expression mean in 4 groups before treatment. The differences among groups was not different significantly (one-way ANOVA, $\mathrm{p}=0.593$ ).

There were significant differences of $\mathrm{CD} 4^{+} \mathrm{IL} 10^{+}$ expression mean ( $\mathrm{t}$-test, $\mathrm{p}=0.004)$ between new-onset nephrotic syndrome before $(1.99 \pm 0.73)$ and after treatment $(3.54 \pm 1.79)$ with prednisone. This finding showed that prednisone treatment increase IL-10 expression (Figure 1).

There were also significant differences of $\mathrm{CD} 4{ }^{+} \mathrm{IL} 10^{+}$expression mean ( $\mathrm{t}$-test, $\left.\mathrm{p}=0.008\right)$ between new-onset nephrotic syndrome before $(3.50 \pm 3.01)$ and after treatment $(9.53 \pm 3.89)$ that treated with combination prednisone and vitamin D3. This finding showed that combination prednisone and vitamin D3 administration increase IL-10 expression (Figure 2).

There was a significant difference of $\mathrm{CD} 4{ }^{+} \mathrm{IL} 10^{+}$ expression mean ( $\mathrm{t}$-test, $\mathrm{p}=0.008$ ) between rarely relapsing nephrotic syndrome before $(1.66 \pm 0.72)$ and af-

Table 1. Mean of CD4 ${ }^{+} \mathrm{IL} 10^{+}$expression

\begin{tabular}{|c|c|c|c|}
\hline Groups & $\begin{array}{c}\text { Mean } \pm \text { SD } \\
\text { (Before Treatment) }\end{array}$ & $\begin{array}{c}\text { Mean } \pm \text { SD } \\
\text { (After Treatment) }\end{array}$ & $\begin{array}{l}P^{\text {-value }} \\
\text { (t-test) }\end{array}$ \\
\hline New-onset NS prednisone + vitamin D3 & $3.50 \pm 3.01$ & $9.53 \pm 3.89$ & 0.008 \\
\hline New-onset NS prednisone only & $1.99 \pm 0.73$ & $3.54 \pm 1.79$ & 0.004 \\
\hline $\begin{array}{l}\text { Rare relapses NS prednisone + vitamin } \\
\text { D3 }\end{array}$ & $1.99 \pm 0.64$ & $4.28 \pm 1.99$ & 0.015 \\
\hline Rare relapses NS prednisone only & $1.66 \pm 0.72$ & $2.78 \pm 2.50$ & 0.008 \\
\hline
\end{tabular}
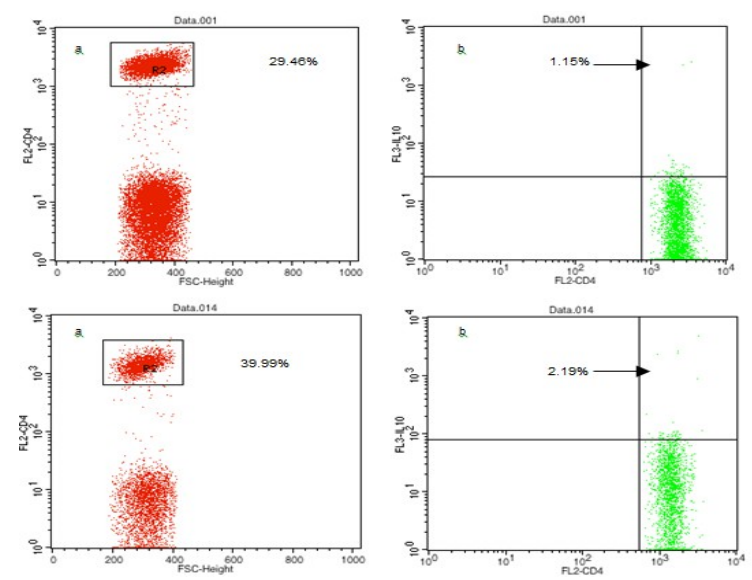

Figure 1. $\mathrm{CD}^{+} \mathrm{IL}-10^{+}$expression before and after prednisone treatment. Upper figure represent before prednisone treatment: $\mathbf{A}$.

$\mathrm{CD}^{+}{ }^{+}$cells number stained with FITC (red) and B. IL-10 expression on $\mathrm{CD}^{+}{ }^{+}$cells stained with PerCP/Cy5.5 (green).

Bottom figure represent after prednisone treatment): A. $\mathrm{CD}^{+}$cells number stained with FITC (red) and B. IL-10 expression on $\mathrm{CD}^{+}$cells stained with PerCP/Cy5.5 (green). 
ter treatment $(2.78 \pm 2.50)$ with prednisone. This finding showed that prednisone treatment increase IL-10 expression. There was also a significant difference of $\mathrm{CD} 4{ }^{+} \mathrm{IL} 10^{+}$expression mean ( $\mathrm{t}$-test, $\left.\mathrm{p}=0.015\right)$ between rarely relapsing nephrotic syndrome before $(1.99 \pm 0.64)$ and after treatment $(4.28 \pm 1.99)$ with combination of prednisone and vitamin D3. This finding showed that combination of prednisone and vitamin D3 treatment increase IL-10 expression.

Figure 3 showed increase of $\mathrm{CD} 4{ }^{+} \mathrm{IL} 10^{+}$expression after treatment both prednisone only or combination prednisone with vitamin D3. Before treatment, $\mathrm{CD}^{+} \mathrm{IL}_{10}{ }^{+}$expression in 3 groups (new-onset nephrotic syndrome treated with prednisone only group, rarely relapsing nephrotic syndrome treated with prednisone only group, rarely relapsing nephrotic syndrome treated with combination of prednisone and vitamin D3) were almost similar. However, in new-onset nephrotic syndrome treated with prednisone and vitamin D3, CD4 ${ }^{+} \mathrm{IL}_{10}^{+}$expression was higher than other groups. It means the first group (new-onset nephrotic syndrome treated with combination of prednisone and vitamin D3) showed the most $\mathrm{CD}^{+} \mathrm{IL} 10^{+}$expression enhancement.

This study showed that $\mathrm{CD} 4^{+} \mathrm{IL} 10^{+}$expression after treatment in 4 groups were statistically different (one-way ANOVA, $\mathrm{p}=0.003$ ) Post-Hoc test showed that there was a significant different of $\mathrm{CD} 4{ }^{+} \mathrm{IL} 10^{+} \mathrm{ex}^{-}$ pression between first group (new-onset nephrotic syndrome treated with combination of prednisone and vitamin D3) and second group (new-onset nephrotic syndrome treated with prednisone only). There was
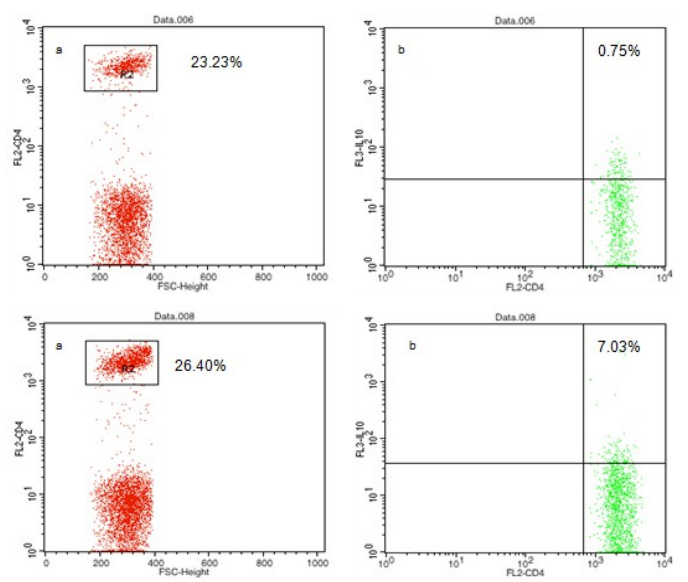

Figure 2. $\mathrm{CD}^{+} \mathrm{IL}_{-10}{ }^{+}$expression before and after prednisone + vitamin D3 treatment. Upper figure represent before prednisone + vitamin D3 treatment: A. CD4 ${ }^{+}$cells number stained with FITC (red) and B. IL-10 expression on $\mathrm{CD}^{+}{ }^{+}$cells stained with PerCP/Cy5.5 (green). Bottom represent after prednisone + vitamin D3 treatment: A. CD4 ${ }^{+}$cells number stained with FITC (red) and B. IL-10 expression on $\mathrm{CD}^{+}$cells stained with PerCP/Cy5.5 (green).
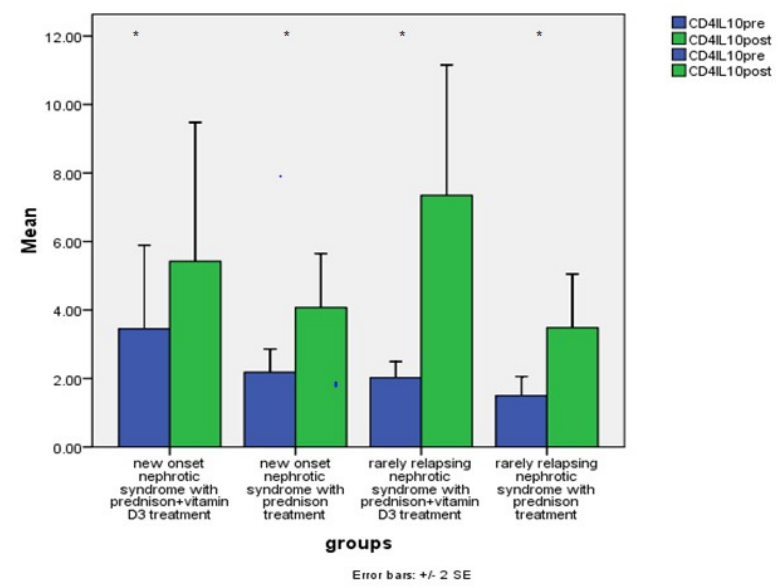

Figure 3. $\mathrm{CD}_{4}{ }^{+} \mathrm{IL}_{10}{ }^{+}$expression before and after treatment among the 4 groups $\left({ }^{*} \mathrm{p}<0.05\right.$ showed statistically different) 
also a significant different of $\mathrm{CD} 4^{+} \mathrm{IL} 10^{+}$expression between first group and third group (rarely relapsing nephrotic syndrome treated with combination of prednisone and vitamin D3), and also first group and fourth group (rarely relapsing nephrotic syndrome treated with prednisone only) (Table 2). with prednisone and vitamin D3). This finding means that treatment with prednisone or prednisone combined with adjuvant vitamin D3 has a beneficial effect to increase $\mathrm{CD} 4^{+} \mathrm{IL}-10^{+}$expression, but addition of vitamin D3 increase CD4 ${ }^{+} \mathrm{IL}-10^{+}$expression more than prednisone-only treated group.

Table 2. Post-hoc LSD analysis of $\mathrm{CD} 4^{+} \mathrm{IL} 10^{+}$expression after treatment

\begin{tabular}{|c|c|c|c|c|}
\hline \multirow[t]{2}{*}{ Groups } & \multirow{2}{*}{$\begin{array}{c}\text { Mean } \\
\text { Differences }\end{array}$} & \multicolumn{2}{|c|}{ IK95\% } & \multirow{2}{*}{$\boldsymbol{P}$} \\
\hline & & Minimum & Maximum & \\
\hline \multicolumn{5}{|l|}{ New-onset NS prednisone+vitamin } \\
\hline $\begin{array}{l}\text { D3 vs New-onset NS prednisone } \\
\text { only }\end{array}$ & 0.424 & 0.142 & 0.706 & $0.005^{*}$ \\
\hline \multicolumn{5}{|l|}{ New-onset NS prednisone+vitamin } \\
\hline $\begin{array}{l}\text { D3 vs Rare relaps NS prednisone } \\
\text { only }\end{array}$ & 0.588 & 0.306 & 0.870 & $0.000^{*}$ \\
\hline \multicolumn{5}{|l|}{ New-onset NS prednisone+vitamin } \\
\hline $\begin{array}{l}\text { D3 vs Rare relaps NS } \\
\text { prednisone+vitamin D3 }\end{array}$ & 0.338 & 0.056 & 0.620 & $0.021^{*}$ \\
\hline \multicolumn{5}{|l|}{ New-onset NS prednisone only vs } \\
\hline \multicolumn{4}{|l|}{ D3 } & 0.533 \\
\hline \multicolumn{5}{|l|}{ New-onset NS prednisone only vs } \\
\hline Rare relaps NS prednisone only & 0.164 & -0.118 & 0.446 & 0.238 \\
\hline \multicolumn{5}{|l|}{ Rare relaps NS prednisone+vitamin } \\
\hline $\begin{array}{l}\text { D3 vs Rare relaps NS prednisone } \\
\text { only }\end{array}$ & 0.250 & -0.032 & 0.532 & 0.007 \\
\hline Significant differences when $\mathrm{P}$-value & & & & \\
\hline
\end{tabular}

\section{Correlation of $C D 4^{+} I L-10^{+}$expression and clinical out- come}

This study showed that there was no correlation between $\mathrm{CD} 4^{+} \mathrm{IL}-10^{+}$expression after prednisone and vitamin D3 treatment with clinical outcome (linear regression test, $\mathrm{p}=0,125)$.

\section{Correlation of $C D 4^{+} I L-10^{+}$expression and $C D 3^{+} G R$ ex- pression}

This study showed that there was a no correlation between $\mathrm{CD}^{+} \mathrm{IL}-10^{+}$expression and $\mathrm{CD}^{+} \mathrm{GR}$ expression after prednison + vitamin D3 treatment $(\mathrm{p}=$ $0.088)$.

In this study we find that there was a significant differences of IL-10 expression between new-onset nephrotic syndrome and rare relaps nephrotic syndrome after treatment with prednisone or prednisone + vitamin D3. CD4 ${ }^{+} \mathrm{IL}-10^{+}$expression increase in all treated groups, but the most enhancement occurred at first group (new-onset nephrotic syndrome treated
Increase of $\mathrm{CD} 4^{+} \mathrm{IL}-10^{+}$expression after glucocorticoid treatment consistent with previous study conducted by Barrat, et al. (2002) that showed glucocorticoid not only increase IL-10 production in T lymphocyte, but also decrease production of IL-4, IL-5 and IL13 in human $\mathrm{T} \mathrm{CD} 4^{+}$cells [22]. Other study showed that renal $\mathrm{T} \mathrm{CD}^{+}$cells was the source of endogenous IL-10 [23]. Glucocorticoid treatment not only up-regulate IL-10 secretion by macrophage/ dendritic cells and Th2 cells, but also involved in Treg proliferation, major immunoregulatory $\mathrm{T}$ lymphocyte subtype that can produce IL-10 abundantly [23]. Glucocorticoid can also trigger IL-10 secretion by $\mathrm{T} \mathrm{CD} 4^{+}$cells directly [24]. Other cells that can be induced to produce IL-10 is monocyte. Mozo, et al. (2004) showed that monocyte, not $\mathrm{T}$ or $\mathrm{B}$ cells, up-regulate IL-10 production (IL-10 protein and mRNA) after treatment with physiologic dose of dexamethasone (after 12 hour). This study suggest that dexamethasone treatment can induce IL-10 production at transcriptional level [25].

$\mathrm{CD}^{+} \mathrm{IL}_{10}{ }^{+}$expression increased significantly in patients with new-onset nephrotic syndrome and rare 
relaps nephrotic syndrome that treated using combination of prednisone and vitamin D3 (compared with prednisone-only treated group). This finding showed that addition of vitamin D3 has beneficial effect in inducing IL-10 expression. Xytraxis et al. (2006) showed that active form of vitamin D3 increase level of IL- $10^{+}$and Foxp3 $3^{+}$cells in human peripheral blood culture [18].

Heine, et al. (2008) demonstrated that calcitriol (an active form of vitamin $\mathrm{D} 3,1,25(\mathrm{OH} 2) \mathrm{D} 3)$ treatment increase both cell number that express IL-10 and the amount of IL-10 expression each cells [26]. Kickler et al. (2012) showed calcitriol induce $\mathrm{T}$ cell population that secrete IL-10. Active metabolite of vitamin D influence $\mathrm{T}$ cell activation mediated by CD46 by controlling the CD46 expression and $\mathrm{T} \mathrm{CD}^{+}$cell and $\mathrm{T}$ $\mathrm{CD}^{+}$cell function. Calcitriol promote switching not only by reduction of IFN- $\gamma$ production, but also promote IL-10 production via CD46 co-stimulation. This study also showed that additional calcitriol treatment can reverse IL-10:IFN- $\gamma$ ratio (increase IL-10 secretion, decrease IFN- $\gamma$ ) in multiple sclerotic patient with decrease of IL-10 production [27].

In vitro study conducted by Allen et al. (2012) demonstrated that there was an increase of IL-10 production by PBMC after vitamin $\mathrm{D}$ treatment, but $\mathrm{T}$ $\mathrm{CD}^{+}$cells frequency that produced IL-10 was not change significantly. Increase of IL-10 production may be caused by vitamin $\mathrm{D}$ effect on monocyte, dendritic cells, or B cells [28].

Glucocorticoid treatment not only increase IL-10 production in $\mathrm{T}$ lymphocyte, but also trigger Treg cells proliferation if administered in combination with active form of vitamin D3, 1,25(OH2)D3. Overall, research data showed that glucocorticoid-only or combination glucocorticoid $+1,25(\mathrm{OH} 2) \mathrm{D} 3$ potentiate Treg immunosuppressive effect by increase IL-10 production and/or Foxp3 expression [29].

Colin et al. (2010) demonstrated 1,25(OH)2D3 inhibit production of TNF- $\alpha$, IL-17 and IFN- $\gamma$, and induce expression of IL-4, IL-5, and IL-10 in PBMC or T $\mathrm{CD}^{+}$cells. Furthermore, 1,25(OH)2D3 increase differentiation of $\mathrm{T} \mathrm{CD}^{+}$cells which produce IL-10 in patients with multiple sclerosis and Crohn disease [30].

1,25(OH)2D3 play an important role for $\mathrm{T}$ lymphocyte proliferation and differentiation. T lymphocyte treatment using calcitriol or its analogs inhibit secretion of various pro-inflammatory cytokines from Th1, Th9 and Th22 cells but induce anti-inflammatory cytokines production from Th2 cells. Calciotropic action of vitamin $\mathrm{D}$ was suggestion for vitamin $\mathrm{D}$ treatment in clinical nephrology. 1,25( $\mathrm{OH}) 2 \mathrm{D} 3$ proven has antiproteinuria effect and inhibit renin angiotensin aldosterone system (RAAS). 1,25(OH)2D3 has a beneficial effect in preserve podocyte structural integrity and functional and also suppress renin expression directly at transcriptional level [31].

T lymphocyte treatment with $1,25(\mathrm{OH}) 2 \mathrm{D} 3$ cause reduction of IL-17, IFN- $\gamma$ and IL-21 level and significantly increase gene expression in Treg cells. Treg cell has anti-inflammatory role and control autoimmune disease by IL-10 and TGF- $\beta$ secretion. Besides that, Treg cell can be induced and stimulated by $1,25(\mathrm{OH}) 2 \mathrm{D} 3$ through indirect pathway via APC and dendritic cells or direct pathway via endocrine effect or intracrine conversion from $25(\mathrm{OH}) \mathrm{D}$ become $1,25(\mathrm{OH}) 2 \mathrm{D} 3$ by Treg cells itself. 1,25(OH)2D3 has a various effect on inflammation and autoimmune disease by decrease Th17 cell population. 1,25(OH)2D3 can also influence $\mathrm{T}$ cell behavior, promote tolerance through Th2 and Treg activity induction and Th1 and Th17 cell activity suppression [31].

In this study, there was no correlation between $\mathrm{CD} 4^{+} \mathrm{IL}_{10}{ }^{+}$expression and clinical outcome. This finding is not consistent with other study that showed short term IL-10 expression could improve glomerulonephritis and glomerulosclerosis. Potential mechanism underlying renoprotective effect of IL-10 maybe complex because IL-10 has a dual action. Major effects of IL-10 are inhibit activation and effector function of $\mathrm{T}$ cells, monocytes, and macrophages. IL-10 bind to its receptor (IL-10R), which this binding can activate several signaling pathway depend on cell type, include pathway that depend on STAT-3, NF-KB and AP-1. IL10 also potentially inhibit several cytokine production such as IL- 1 and TNF- $\alpha$, chemokine such as MCP-1 and RANTES in activated monocyte/ macrophage, and also suppress MCP-1 in inflammatory cell population (this effect can delay monocyte/ macrophage recruitment in renal interstitium). IL-10 also inhibits dendritic cell function and $\mathrm{T}$ cell activation [32]. However, correlation between IL-10 expression and clinical outcome need further investigation.

\section{CONCLUSIONS}

We conclude that $\mathrm{CD} 44^{+} \mathrm{IL}-10^{+}$expression in nephrotic syndrome patient (new-onset and rare relapses) were higher in prednisone + vitamin D3 treated group than prednisone-only treated group. This study also concluded that there is no correlation between $\mathrm{CD} 4^{+} \mathrm{IL}-10^{+}$expression and $\mathrm{CD}^{+} \mathrm{GR}$ expression nor $\mathrm{CD} 4^{+} \mathrm{IL}-10^{+}$expression and clinical outcome. 


\section{ACKNOWLEDGMENT}

We would like to thank the Department of Child Health, Faculty of Medicine, University of Brawijaya/ dr.Saiful Anwar General Hospital, Malang, Indonesia for providing the grant to accomplish this research. We also thank to Wahyuda Ngatiril Lady S.Si, from Biomedical Laboratory of Medical Faculty, Biomedical Laboratory of Medical Faculty, Brawijaya University for his good assistance in flowcytometry.

\section{REFERENCES}

1. Zhang S, Audard V, Fan Q, Pawlak A, Lang P, Sahali L (2011) Immunopathogenesis of Idiopathic Nephrotic Syndrome. Contributions to Nephrology. 169: 94-106.

2. Bagga A (2008) Management of steroid sensitive nephrotic syndrome:revised guidelines. Indian Pediatrics. 45: 203-14.

3. Roth KS, Amaker BH, Chan JCM (2002) Nephrotic Syndrome: Pathogenesis and Management. Pediatr Rev. 23: 237-47.

4. Krisni (2007) Pola penyakit ginjal pada anak di RS Saiful Anwar Malang tahun 2002-2006. Disampaikan pada Pertemuan Ilmiah Tahunan Ilmu Kesehatan Anak Ikatan Dokter Anak Indonesia (PIT IKA-IDAI). Yogyakarta.

5. Hafez MA, Shimada M, Lee PY, Johnson RJ, Garin EH (2009) Idiopathic Nephrotic Syndrome and Atopy: Is There a Common Link?, American Journal of Kidney Diseases. 54(5): 945-53.

6. Grimbert P, Audard V, Remy P, Lang P, Sahali D (2003) Recent Approaches to The Pathogenesis of MinimalChange Nephrotic Syndrome. Nephrol Dial Transplant. 18: $245-8$.

7. Jafar T, Agrawal S, Mahdi AA, Sharma RK, Awasthi S, Agrawal GG (2011) Cytokine gene polymorphisms in idiopathic nephrotic syndrome children. Ind J Clin Biochem. 26: 296-302

8. Berg JG, Weening JJ (2004) Role of the immune system in pathogenesis of idiopathic nephrotic syndrome. Clinical Science. 107: 125-36.

9. Gipson DS, Massengill SF, Yao L, Nagaraj S, Smoyer WE, Mahan JD, Wigfall D, Miles P, Powell L, Lin J, Trachtman H, Greenbaum LA (2009) Management of Childhood Onset Nephrotic Syndrome. Pediatrics. 124(2): 74757.

10. Greenbaum LA, Benndorf R, Sinoyer WE (2012) Childhood nephrotic syndrome-current and future therapies. Nat Rev Nephrol. 8: 445-58.

11. Carlotti P, Franco PB, Ellas LL, Facincani I, Costa C, Foss N, Moreira AC, Castro M (2004) Glucocorticoid receptors, in vitro sensitivity, and cytokine secretion in idio- phatic nephrotic syndrome. Kidney Int. 65: 403-8.

12. Charmandari E, Kino T, Chrourus GP (2004) Molecular mechanisms of glucocorticoid action. Orphanet. 1-8.

13. Necela BM, Cidlowski JA (2004) Mechanisms of glucocorticoid receptor action in noninflammatory and inflammatory cells. Proc Am Thorac Soc. 1: 239-46.

14. Webster JI, Tonelli L, Sternberg EM (2002) Neuroendocrine Regulation of Immunity. Annu Rev Immunol. 20: 125-63.

15. Asadullah K, Sterry W, Volk HD (2003) Interleukin-10 therapy-review of a new approach. Pharmacol Rev. 55: 241-69.

16. Roque S, Correia-Neves M, Mesquita AR, Palha JA, Sousa N. Interleukin-10: A Key Cytokine in Depression?. Cardiovascular Psychiatry and Neurology. 2009:1-5.

17. Wu K, Bi Y, Sun Y, Wang C (2007) IL-10 Producing Type 1 Regulatory $\mathrm{T}$ Cells and Allergy. Cellular \& Molecular Immunology. 4: 269-75.

18. Xytrakis E, Kusumakar S, Baswell S, Peek E, Urry Z, Richard DF, Adikibi T, Pridgeon C, Dallman M, Loke T, Robinson DS, Barrat FJ, O'Garra A. Lavender P, Lee TH, Corrigan C, Hawrylowicz CM (2006) Reversing the Defective Induction of IL-10-Secreting Regulatory T Cells in Glucocorticoid-Resistant Asthma Patients. J Clin Invest. 116: 146-55.

19. Takeda M, Yamashita T, Sasaki N, Nakajima K, Kita T, Shinohara M, Ishida T Hirata K (2010) Oral Administration of an Active Form of Vitamin D3 (Calcitriol) Decreases Atherosclerosis in Mice by Inducing Regulatory $\mathrm{T}$ Cells and Immature Dendritic Cells With Tolerogenic Functions. Arterioscler Thromb Vasc Biol. 30: 2495-503.

20. Terrier B, Derian N, Schoindre Y, Chaara W, Geri G, Zahr N, Mariampillai K, Rosenzwajg M, Carpentier W, Musset L, Piette JC, Six A, Klatzmann D, Saadoun D 1, Patrice C, Chalumeau NC (2012) Restoration of regulatory and effector $\mathrm{T}$ cell balance and $\mathrm{B}$ cell homeostasis in systemic lupus erythematosus patients through vitamin $\mathrm{D}$ supplementation. Arthritis Research \& Therapy. 14: 1-10.

21. Urry Z, Chambers EM, Xytrakis E, Dimoloe S, Richards DF, Gabrysova L (2012) The role of 1 $\alpha, 25$-dihydroxyvitamin D3 and cytokines in the promotion of distinct Foxp3+ and IL-10+CD4+ T cells. Eur J Immunol. 42: 2697-708.

22. Barrat FJ, Cua DJ, Boonstra A, Richards DF, Crain C, Savelkoul HF, Waal-Malefyt R, Coffman RL, Hawrylowicz CM, O'Garra A (2002) In vitro generation of interleukin 10-producing regulatory CD4+ T cells is induced by immunosuppressive drugs and inhibited by $\mathrm{T}$ helper yype 1 (Th1)- and Th2-inducing cytokines. J. Exp. Med. 195: 603-16.

23. Scholz J, Kornek VL, Engel DR, Specht S, Kiss E, Eitner 
F, Floege J, Groene HJ, Kurts C (2008) Renal dendritic cells stimulate IL-10 production and attenuate nephrotoxic nephritis. J Am Soc Nephrol. 19: 527-37.

24. Franchimont D (2004) Overview of the Actions of Glucocorticoids on the Immune Response A Good Model to Characterize New Pathways of Immunosuppression for New Treatment Strategies. Ann NY Acad Sci. 1024: 12437.

25. Mozo L, Suarez A, Gutierrez C (2004) Glucocorticoids up-regulate constitutive interleukin-10 production by human monocytes. Clin Exp Allergy. 34: 406-12.

26. Heine G, Niesner U, Chang H, Steinmeyer A., Zugel U, Zuberbier T, Radbruch A, Worm M (2008) 1,25-dihydroxyvitamin D3 Promotes IL-10 Production in Human B Cells. Eur. J. Immunol. 38: 2210-8.

27. Kickler K, Choileain SN, Williams A, Richards A, Astier AL (2012) Calcitriol Modulates the CD46 Pathway in T Cells. PLoS ONE. 7: 1-11.

28. Allen AC, Kelly S, Basdeo SA, Kinsella K, Mulready KJ, Kingston HG, Mills KHG, Tubridy N, Walsh C, Brady JJ, Hutchinson M, Fletcher JM (2012) A pilot study of the immunological effects of high-dose vitamin D in healthy volunteers. Multiple Sclerosis Journal. 18: 1797-800.

29. Heijink IH, Van Oosterhout AJM (2006) Strategies for targeting T-cells in allergic diseases and asthma. Pharmacology \& Therapeutics. 112: 489-500.

30. Colin EM, Asmawidjaja PS, Van Hamburg JP, Mus AMC, Van Driel M, Hazes JMW, Van Leeuwen JPTM, Lubberts E (2010) 1,25-Dihydroxyvitamin D3 Modulates Th17 Polarization and Interleukin-22 Expression by Memory $\mathrm{T}$ Cells From Patients with Early Rheumatoid Arthritis. Arthritis \& Rheumatism. 62: 132-42.

31. Lang CL, Wang MH, Chiang CK, Lu KC (2014) Vitamin $\mathrm{D}$ and the Immune System from the Nephrologist's Viewpoint. ISRN Endocrinology. 2014: 1-11.

32. $\mathrm{Mu} \mathrm{W}$, Ouyang X, Agarwal A, Zhang L, Long DA, Cruz PE, Roncal CA, Glushakova OY, Chiodo VA, Atkinson MA, Hauswirth WW, Flotte TR, Iturbe BR, Johnson RJ (2005) IL-10 Suppresses Chemokines, Inflammation, and Fibrosis in a Model of Chronic Renal Disease. J Am Soc Nephrol. 16: 3651-60. 